\title{
Research on Risk Prevention and Control of Sino- foreign Cooperative Universities - Based on ERM Comprehensive Risk Management Framework
}

\author{
Hao Wang \\ Guangzhou College of South China University of \\ Technology \\ Guangzhou, China 510800 \\ Chunwen Ren \\ Guangzhou College of South China University of \\ Technology \\ Guangzhou, China 510800
}

\author{
Jinpeng Wang \\ Guangzhou College of South China University of \\ Technology \\ Guangzhou, China 510800 \\ Shiyu Zhang \\ Guangzhou College of South China University of \\ Technology \\ Guangzhou, China 510800
}

\begin{abstract}
Cooperation between Chinese and foreign universities is an inevitable trend of the internalization of higher education. With the expansion of school-running scale in China, there hasn't been a complete set of theoretical system of risk prevention and control management of Sino-foreign cooperative education universities. This paper will explore the possibility of applying the ERM framework in China's higher education, based on the ERM framework which is the most widely accepted risk management framework at present and the case of the University of California which has already applied this framework.
\end{abstract}

Keywords-comprehensive risk management framework; higher education; risk management; cooperative education

\section{INTRODUCTION}

The internationalization of higher education is the inevitable trend of economic globalization. China's internalization of higher education has experienced international exchanges, international cooperation, and gradually towards international certification and other more diversified directions. Sino-foreign cooperation in running schools is an important carrier of international cooperation and an important way of internalization of higher education. Compared with ordinary higher education, Sino-foreign cooperation in running schools has obvious particularity because of the governance structure of both Chinese and foreign parties. Thus, this particular form of Sino-foreign cooperation in running schools produced some risk rarely seen in higher education in general. If these risks cannot be effectively prevented and controlled, it will directly affect the reputation and the sustainable development of Chineseforeign cooperative education, and the serious risk outbreak will also likely cause a crisis of survival to the Sino-foreign cooperative education institution or program.

As a risk management method, the comprehensive risk management framework has become an effective way of risk management for listed companies and large enterprises after more than ten years' improvement and practice. At the same time, many foreign educational management institutions and universities have gradually introduced this system to the daily school management. Therefore, it is an inevitable trend to apply this approach to the risk management of higher education, especially to the risk management of Sino-foreign cooperative institutions and programs.

\section{THE EVOLUTION AND DEVELOPMENT OF RISK MANAGEMENT IN UNIVERSITIES}

The National Association of College and University Business Officers (NACUBO) and Pricewaterhouse Coopers $(\mathrm{PwC})$ both issued "Developing a Strategy to Manage Enterprise wide Risk Management in Higher Education" in 2001 [1], which defines risks and 20 risk drivers, introduces some methods of risk management and monitoring and how to apply them to campus management. At the same time, the Higher Education Funding Council for England (HEFCE) also initiated the introduction of risk management into British universities and wrote the related report [2] on risk management. In the report, it explains the concept of risk management and some application cases in detail, especially the types of risks that higher education institutions may face. In 2003, the University Risk Management and Insurance Association (URMIA) [3] stated the benefits of implementing risk management strategies in universities and how to carry out the risk management.

In 2004, the United States Committee of Sponsoring Organizations of the Treadway Commission (COSO) put forward the "comprehensive risk management: Enterprise Risk Management Integrated Framework" (ERM) [4], [5]. This framework has milestone significance and is widely adopted by global listed companies and large enterprises. It provides the standard language of risk management, and its operation rules are easy to operate; the framework is 
gradually being promoted to non-profit organizations, such as universities and hospitals. The ERM framework has three dimensions, which are objective dimension, rank dimension and risk factor dimension. The three dimensions are interrelated. Hierarchy is the main body of management, as shown in "Fig. 1".

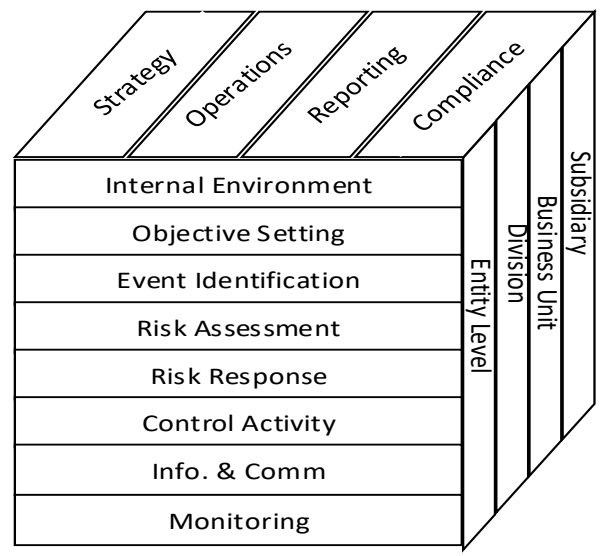

Fig. 1. Three dimensions in ERM integrated framework.

In 2007, the Association of Governing Boards of Universities and Colleges (AGB) and National Association of College and University Business Officers (NABUBO) jointly convened an Education Summit in Washington, D.C., at which a report entitled "Meeting the Challenges of Enterprises: Risk Management in Higher Education" was issued [6]. The implementation of the ERM framework in
University risk management was described in detail, and the Higher-education-specific model, aiming at the ERM framework model of higher education was also developed. In the same year, the URMIA published a white paper entitled "ERM Framework for Higher Education Management"[7]. It compares the differences between the implementation of ERM framework in Colleges and universities and ordinary enterprises and introduces the method templates and reference information for the implementation of ERM framework. At the same time, four universities, such as the University of California and Pennsylvania State University, are listed as cases of sharing the specific situation of implementing ERM in Colleges and universities. In 2008, PricewaterhouseCoopers discussed the method of implementing the comprehensive risk management framework of ERM in Colleges and universities [8], and put forward the parallel strategy, which is the integration of the existing risk management system and ERM, as shown in "Fig. 2". On the other hand, the HEFCE initiated the introduction of risk management and wrote it in 2001 [2], long before COSO proposed the ERM framework. That is the first report on risk management in Colleges and universities and introduces the concept of risk management and some application cases in detail, especially lists the types of risks that institutions of higher education may face. PricewaterhouseCoopers wrote "Risk management in higher education a guide to good practice" [9], which divides the operational process of risk management into two directions: top-down strategic perspective and bottom-up specific operational perspective, two directions of the dynamic cycle to ensure that the system has a competitive advantage.

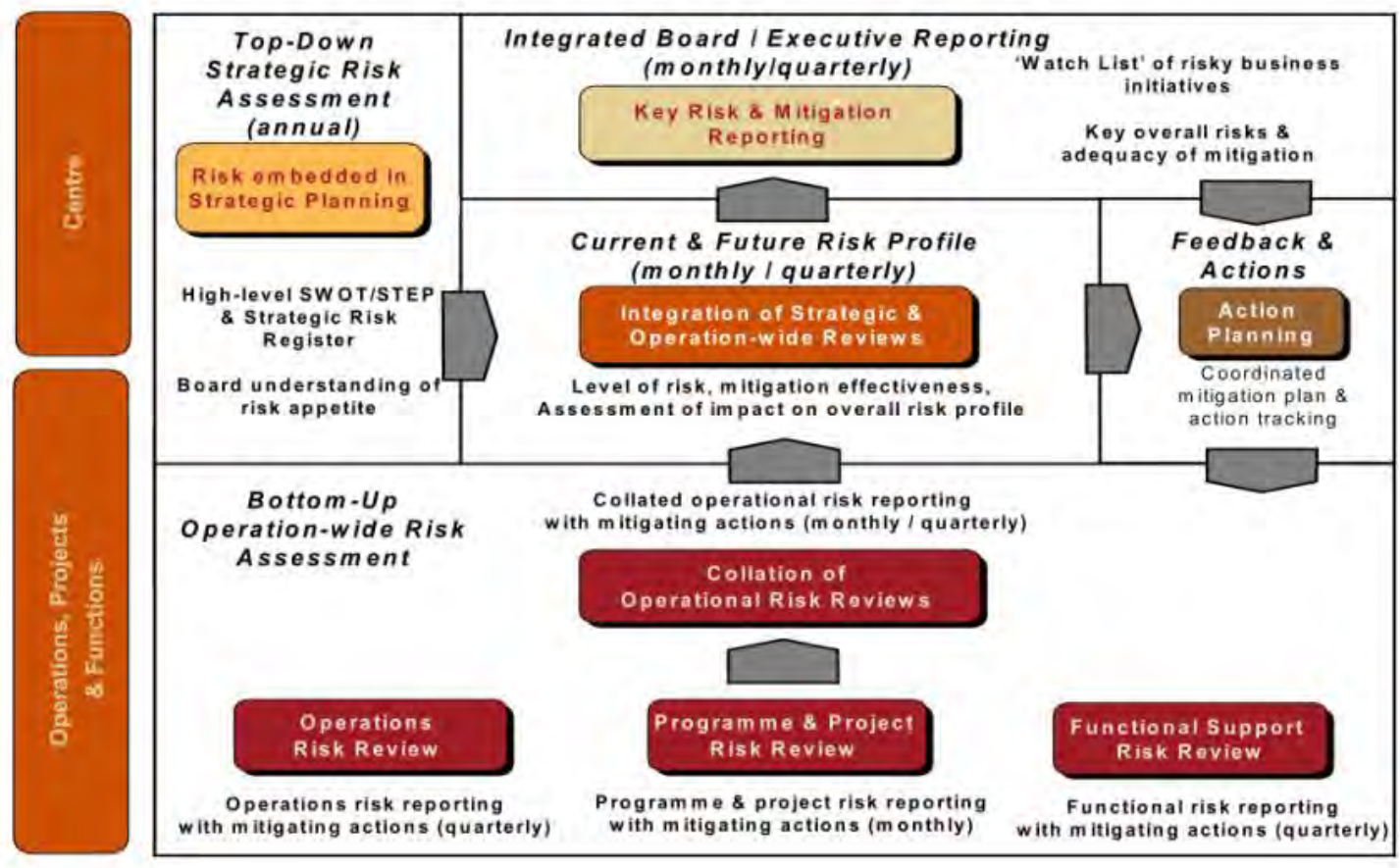

Fig. 2. ERM process.[9]

Australia and New Zealand issued "AS/NZS 4360: 2004: risk management" in 2004 [10], which is similar to the ERM framework, comprising 7 elements and 8 management processes, followed by a companion handbook on risk Management guidelines for the standard [11], which details the specific steps and implementation of risk management. 
The University of California (referred to as UC) is the first institution to carry out risk management in Colleges and universities. In 1996, it adopted the internal control framework of COSO [12], set up the position of risk management in November 2004, and completed the work of risk-control specialist group in major campus and affiliated medical schools in 2007, and officially launched the riskcontrol information system in 2008, which implemented the collection and sharing of risk-information at school level. In 2009, ERM Maturity Model was developed on the basis of the ERM model. In the following years, the risk-control management of UC has received high praise from many institutions including standard \&Poor's, and has become a demonstration unit for risk management in Colleges and universities. The risk management preparation work of UC is divided into three steps. The first step is to set up the expert group, the second step is to write the corresponding regulations, and the third step is to formulate corresponding plans. In particular, the third step is based on the eight elements of the ERM framework: environment, objectives, event identification, risk assessment, risk response, control events, information communication and monitoring. In formulating the specific steps of the plan, UC describes each element, including the general objectives, sub goals, areas of focus, specific work items, expected results and assessment methods, corresponding leadership and timetable. Meanwhile, according to the particularity of university management, UC divides risk into 8 categories [13]: (1) disaster risk, (2) financial risk, (3) IT risk, (4) human resources risk, (5) research risk, (6) legal and compliance risks, (7) campus life risk, and (8) facility maintenance risk. In practice, UC has created a series of tools for risk management.

\section{IMPLICATIONS ON RISK MANAGEMENT OF HIGHER EDUCATION IN CHINA}

China's research and application in the field of risk management started late. In June 2006, the State-owned Assets Supervision and Administration Commission
(SASAC) issued the "Comprehensive risk management guidelines for state owned enterprises" [14], which is China's first comprehensive risk management guidance document, which means China has embarked on the stage of risk management. In June 2008, the five departments such as the Ministry of Finance jointly issued "The standard of enterprises internal control"[15], and jointly issued the "Guidelines for enterprise internal control" in April 2010[16]. This indicates that the internal control standard system of Chinese enterprises is basically established to adapt to China's actual conditions and integrate advanced international experience. However, compared with the upgrading from internal control to risk management framework in Europe and America, China is still in the initial stage of research and application. Fang Hongxing, Professor of accounting at Dongbei University of Finance and Economics, translated COSO's ERM framework[17] as an important reference for China's internal control to enhance overall risk management, laying the foundation for research in related fields.

According to the author's research on higher education risk management, this paper designs a risk assessment matrix suitable for higher education in China and divides the probability and control effectiveness of each risk into 5 grades respectively, the higher the rank, the greater the influence, the greater the probability and the higher the effectiveness of the corresponding control. At the time of defining the risk level, the index of influence and probability synthesis is considered, the initial weight is $50 \%$, and the manager can adjust the weight distribution according to the actual situation. In this risk management matrix, a total of 49 risks for 8 categories will be assessed according to the above process, followed by a higher level of risk, with high likelihood of impact, and greater attention when allocating resources.

- Higher education risk assessment matrix, which is used to identify, evaluate, monitor and respond to different kinds of risks, as shown in "Fig.3".

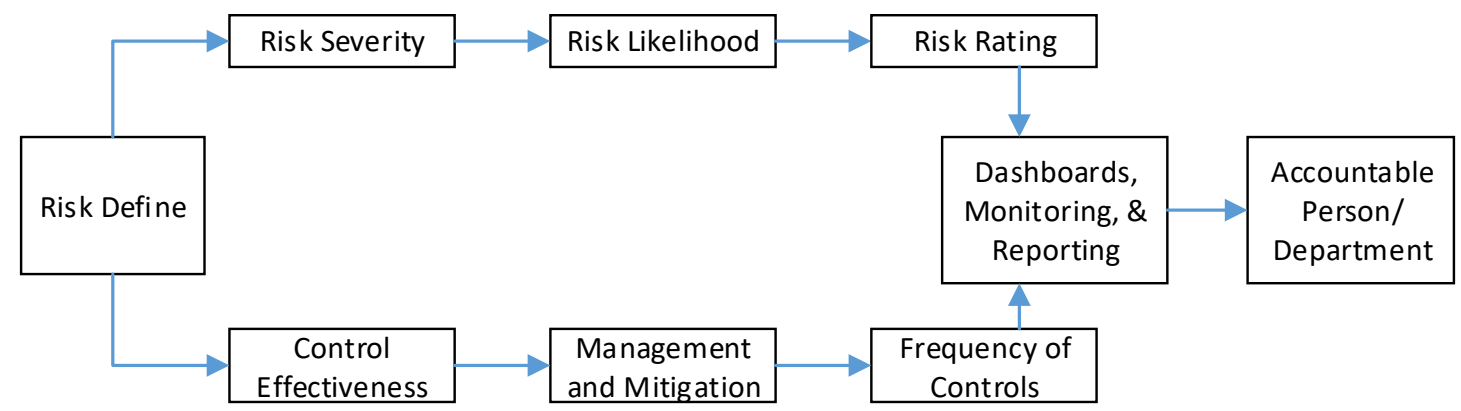

Fig. 3. Higher education risk evaluation flow.[13]

- The risk control structure assessment tool, because of the effectiveness of the current risk control, is similar to the risk assessment matrix of higher education. The first step is to define the grade and weight, and then to assess the risk. What is the impact of prediction when control fails? How big the impact will be?
- Risk Management Budget Assessment, which is used to assess the cost of each risk management and the potential benefits by reducing risk or gaining, and then to achieve the best risk management model through a more reasonable budget distribution. The major steps are: 
TABLE I. MAJOR STEPS OF BUdget AsSESSMENT

\begin{tabular}{|l|l|}
\hline Step 1: & List possible budget reduction actions. \\
\hline Step 2: & Consider potential benefits. \\
\hline Step 3: & Consider risks to environment and life safety. \\
\hline Step 4: & Estimate potential financial severity. \\
\hline Step 5: & Consider the risk of mission impairment. \\
\hline Step 6: & Consider impacts to stakeholders. \\
\hline Step 7: & Consider reputational risk. \\
\hline Step 8: & Determine whether separation of duties is compromised. \\
\hline Step 9: & Decide which actions to implement. \\
\hline
\end{tabular}

\section{RISK ASSESSMENT OF COOPERATIVE EDUCATION BASED ON ERM FRAMEWORK}

By combing risk cases within the portion of the Sinoforeign cooperative education institution in mainland China and contrast eight major risk classification of the $\mathrm{UC}$, that are (a) hazard risk, (b) financial risk, (c) information technology risk, (d) human resource risk, (e) research risk, (f) campus risk, (g) facilities \& maintenance risks, we have modified the (h) legal, contract and grant risk category by add three specific risk in cooperative education, and created a new category (i) teach and student administration with three risks as well. They are shown in "Table II".

TABLE II. Risk Evaluation MATRIX ChangEd For CORPORATIVE EdUCATION

\begin{tabular}{|c|c|c|c|}
\hline ID & Risk Category & Risk Name & Risk Description \\
\hline h. 1 & $\begin{array}{l}\text { Legal, Contract } \\
\text { and rant } \\
\text { Risks }\end{array}$ & $\begin{array}{l}\text { violate the law } \\
\text { in either country }\end{array}$ & $\begin{array}{l}\text { Sino-foreign cooperation in running a school is a policy-oriented activity, which is } \\
\text { influenced and restricted by many policies, such as Sino-foreign cooperation in } \\
\text { running a school, diploma certification policy, foreign education policy, foreign } \\
\text { exchange management policy, tax policy, and education service trade policy under } \\
\text { the WTO framework. At the same time, it is also a cross-border and cross-cultural } \\
\text { school-running model involving multi-stakeholders (both sides of the school, } \\
\text { investors, school staff, project students and parents, etc.). "In the specific process of } \\
\text { running a school, the obvious loss of the interests of one party, the contractual } \\
\text { relationship between the interests of the main body, the unclear definition of rights } \\
\text { and obligations will cause arbitration, legal proceedings and other legal disputes." }\end{array}$ \\
\hline h. 2 & $\begin{array}{l}\text { Legal, Contract } \\
\text { and rd Grant } \\
\text { Risks }\end{array}$ & $\begin{array}{l}\text { Foreign partner } \\
\text { fails to fulfill } \\
\text { the agreement }\end{array}$ & $\begin{array}{l}\text { According to the regulations on Sino foreign cooperation in running schools issued } \\
\text { by the State Council in March 2003, the main teaching activities of Sino-foreign } \\
\text { cooperative institutions are completed in China and the main body of recruitment is } \\
\text { Chinese citizens. China must invest a large amount of human property in all aspects } \\
\text { of enrollment, teaching, teacher remuneration and so on, to ensure the smooth } \\
\text { implementation of the project. Based on the great disparity between the strength and } \\
\text { discipline level of the two sides and the intermarriage of transnational education, } \\
\text { some foreign parties tend to take economic interests as the main driving force, while } \\
\text { maintaining their academic standards and degree awarding standards, resulting in a } \\
\text { lower level of discourse power and unequal responsibilities and responsibilities. The } \\
\text { question is, the Chinese side must pay the bill. }\end{array}$ \\
\hline h. 3 & $\begin{array}{l}\text { Legal, Contract } \\
\text { and Grant } \\
\text { Risks }\end{array}$ & $\begin{array}{l}\text { Foreign } \\
\text { education } \\
\text { certification } \\
\text { issued by } \\
\text { Chinese CHED }\end{array}$ & $\begin{array}{l}\text { The education administrative department has various interpretations and } \\
\text { certifications for the academic degrees of Sino-foreign cooperative education } \\
\text { programs, including academic attestation, degree certification, and study abroad } \\
\text { certification. Under the premise that students and parents are indistinct about these } \\
\text { concepts, some Chinese foreign cooperative education institutions or projects give } \\
\text { "cooperation in running schools" in enrollment. "Joint training" and other nouns, so } \\
\text { that students and parents of academic degree certification is in a fog, and even some } \\
\text { students have been inducted into the examination and have applied for examination } \\
\text { without approval by the administrative department of education, so that the degree } \\
\text { of foreign degree cannot be certified at graduation. }\end{array}$ \\
\hline i. 1 & $\begin{array}{l}\text { Teach and } \\
\text { student } \\
\text { administration }\end{array}$ & $\begin{array}{l}\text { Conflicts of } \\
\text { teaching } \\
\text { management } \\
\text { between two } \\
\text { universities }\end{array}$ & $\begin{array}{l}\text { It is difficult to form a unique curriculum system integrating Chinese and Western } \\
\text { science without the full consultation and convergence of teaching syllabus, training } \\
\text { plan, teaching methods, teaching materials and assessment methods. The actual } \\
\text { situation is often "one brand, two teams", the two sides teach each other in their } \\
\text { own way. Some foreign students temporarily or randomly transfer foreign teachers } \\
\text { to the Chinese side each semester. The high mobility of foreign teachers, the lack of } \\
\text { professionalism of teachers, the low degree of integration of teaching teams at home } \\
\text { and abroad, and the two sets of salary and evaluation system aiming at Chinese and } \\
\text { foreign teachers make many projects lack of scientific, systematic and continuous } \\
\text { teaching. }\end{array}$ \\
\hline i. 2 & $\begin{array}{l}\text { Teach and } \\
\text { student } \\
\text { administration }\end{array}$ & $\begin{array}{l}\text { Student } \\
\text { enrollment, } \\
\text { insufficient } \\
\text { number } \\
\text { enrolled } \\
\text { students }\end{array}$ & $\begin{array}{l}\text { As a new mode of higher education, the rapid development of the local study abroad } \\
\text { craze has caused the situation of sediment accumulation. According to the Ministry } \\
\text { of Education's "Circular on the Recent Situation of Sino-foreign Cooperation in } \\
\text { Running Schools of Higher Education" (No. 1210, Department of Education for } \\
\text { Foreign Affairs, 2013), some foreign universities in China carry out chain-store- } \\
\text { style low-cost duplication of running schools, in addition to some intermediaries } \\
\text { participating in packaging and even contracting the preparatory work of Sino- } \\
\text { foreign cooperation in running schools, cooperative partners, colleges and } \\
\text { universities. The phenomenon of low-level duplication and homogenization }\end{array}$ \\
\hline
\end{tabular}




\begin{tabular}{|c|c|c|c|}
\hline ID & Risk Category & Risk Name & Risk Description \\
\hline i. 2 & $\begin{array}{l}\text { Teach and } \\
\text { student } \\
\text { administration }\end{array}$ & $\begin{array}{l}\text { Student } \\
\text { enrollment, } \\
\text { insufficient } \\
\text { number } \\
\text { enrolled } \\
\text { students }\end{array}$ & $\begin{array}{l}\text { competition is increasingly prominent. Some of the cooperative programs are not } \\
\text { attractive because of the reputation of Chinese or foreign cooperative colleges, non- } \\
\text { US, UK, Canada and Australia as the preferred destination for study, coupled with } \\
\text { high fee threshold, and the lack of attractiveness of the project, there is a } \\
\text { phenomenon of directly reducing batch admission or individual code admission in } \\
\text { violation of the policy. }\end{array}$ \\
\hline i. 3 & $\begin{array}{l}\text { Teach and } \\
\text { student } \\
\text { administration }\end{array}$ & $\begin{array}{l}\text { fail to meet the } \\
\text { teaching } \\
\text { target,students } \\
\text { are not satisfied } \\
\text { by employer }\end{array}$ & $\begin{array}{l}\text { Academic and cultural differences between China and foreign universities in } \\
\text { admissions and degree awards; high project fees, high expectations from society, } \\
\text { parents and students on the project and project quality gaps; high-intensity } \\
\text { curriculum system oriented by high professional points and high foreign language } \\
\text { achievement, and through reduction Contradictions and civil disputes between the } \\
\text { sponsors and the students resulted from the disparity between the volunteers and the } \\
\text { low-quality students enrolled by individual codes. }\end{array}$ \\
\hline
\end{tabular}

We have rated six new risks with their severity, likelihood and follow the default weight (50\% to severity, $50 \%$ to likelihood) and define the risk impact as follow:

$$
\begin{aligned}
\text { risk impact }= & \text { severity num } \times \% \text { severity } \\
& + \text { likelihood num } \times \% \text { likelihood }
\end{aligned}
$$

Each category is represented by the average of severity number, likelihood and impact, as shown in the following "Fig. 4".

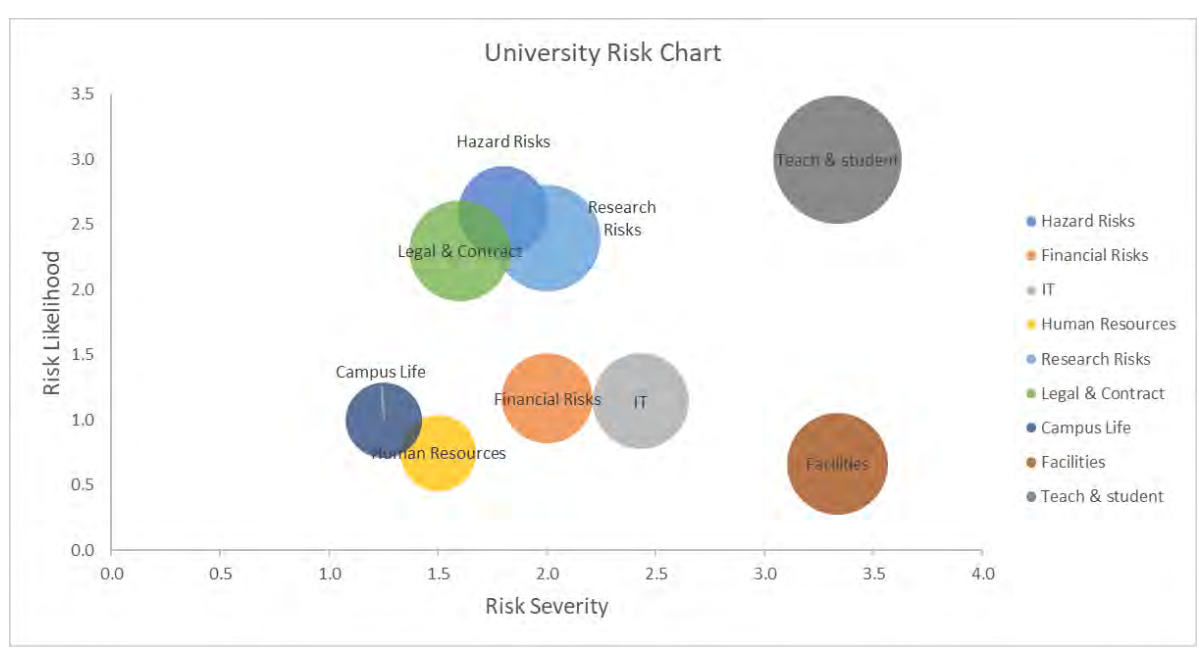

Fig. 4. Bubble chart for cooperative education risk.

We find that teach and student administration ranks first with category impact number 3.2, this is much higher than second and third risks which are research and hazard risks. On the other side, campus and human resource are two with lowest impact number, it is not surprised that both regular and cooperative education have the same situation regarding the HR and campus security.

\section{CONClusion}

Therefore, it is necessary to strengthen the self-regulation of the running scholars based on the external supervision of the administrative departments of education and form a risk prevention and control mechanism that combines scholars, governments and social multi subjects, and conduct in-depth and comprehensive identification and analysis of various risks, so that Sino-foreign cooperative universities can effectively avoid or control all kinds of risks. Risks, and achieve the goal of steady and healthy development of Sinoforeign cooperative universities.

\section{REFERENCES}

[1] Cassidy, D., et al., Developing a strategy to manage enterprisewide risk in higher education. Washington, DC: NACUBO and Pricewaterhouse Coopers LLP, 2001.

[2] Coopers, P., Risk management: A guide to good practice for higher education institutions. 2001.

[3] Jane Dickerson, P.F.a.L.F., Enterprise Risk Management: A Fundamental Practice for Higher Education. 2003, University Risk Management and Insurance Association.

[4] Commission, C.o.S.O.o.t.T., Enterprise Risk Management Integrated Framework: Application techniques. 2004: COSO.

[5] Commission, C.o.S.O.o.t.T., Enterprise Risk Management Integrated Framework: Executive Summary Framework. 2004: COSO.

[6] Mattie, J., Meeting the Challenges of Enterprise Risk Management in Higher Education. National Association of College and University Business Officers (NJ1), 2007.

[7] Morris, V., URMIA White Paper: ERM in Higher Education. 2007.

[8] Mattie, J. and D. Cassidy, Achieving goals, protecting reputation: Enterprise Risk Management for Educational Institutions. 2008. 
[9] Coopers, P., Risk management in higher education: a guide to good practice, prepared for Hefce by PricewaterhouseCoopers. 2005

[10] International, S.A. and S.N. Zealand, AS/NZS 4360: 2004: risk management. 2004: Standards New Zealand.

[11] International, S.A. and S.N. Zealand, HB 436: 2004 Risk Management Guidelines companion to AS/NZS 4360: 2004. 2004.

[12] California, E.P.U.o., University of California Enterprise Risk Management Report 2012. 2012.

[13] President, U.o.C.O.o. Higher education risk assessment tool. 2012; Available from: https://www.ucop.edu/enterprise-riskmanagement/tools-templates/risk-assessment-toolbox.html.

[14] Commission, S.-o.A.S.a.A., Comprehensive risk management guidelines for central enterprises. 2006.

[15] The Ministry of finance, t.S.R.C., the Audit Commission, the Banking Regulatory Commission and the China Insurance Regulatory Commission, the standard of enterprises internal control. 2008.

[16] The Ministry of finance, t.S.R.C., the Audit Commission, the Banking Regulatory Commission and the China Insurance Regulatory Commission, guidelines for enterprise internal 2010.

[17] Fang, H., Internal Control - Integrated Framework, Dalian, China: Dongbei University of Finance and Economics Press. 2008 